\title{
STUDI PENANGANAN KERUSAKAN PANTAI DI KAWASAN WISATA PESISIR TELUK KUPANG
}

\author{
Priska Gardeni Nahak ${ }^{1 *}$, Melchior Bria ${ }^{2}$, Mathelda C.H. Mauta ${ }^{3}$ \\ 1,2.3 Jurusan Teknik Sipil, Politeknik Negeri Kupang \\ Jln. Adisucipto Penfui Kupang \\ ‘E-mail: prigardeni@yahoo.com
}

\begin{abstract}
Abstrak
Lokasi wisata di pesisir Teluk Kupang yang berkembang pesat saat ini adalah Pantai Tedys di Kelurahan Lai-Lai Besi Kopan (LLBK). Pantai Tedys ini merupakan salah satu pusat pariwisata dan Pusat perdagangan di Kota Kupang. Lokasi ini merupakan pusat wisata kuliner yang sangat ramai oleh pengunjung setiap harinya, dan juga merupakan lokasi persinggahan kapal-kapal asing peserta Sail Indonesia dan Sail Komodo. Berkembangnya berbagai kepentingan tersebut membuat wilayah pesisir di kelurahan LLBK akan menyanggah beban lingkungan yang berat, akibat pemanfaatan yang tidak terkendali, tidak teratur, serta tidak mempertimbangkan penggunaan teknologi yang ramah lingkungan. Penelitian ini menggunakan metode deskripsi dengan melakukan observasi dan kajian secara langsung di lapangan terhadap berbagai kondisi guna mengetahui seberapa besar dampak dan kerusakan yang mungkin terjadi. Penelitian ini bertujuan untuk: a Mengidentifikasi kerusakan pantai pada Kawasan Wisata di Pesisir Teluk Kupang. b) Mengetahui tingkat kerusakan dan pengaruhnya terhadap lingkungan di sekitarnya, c) Menentukan upaya penanganan yang dapat dilakukan guna meminimalisir kerugian yang mungkin terjadi. Berdasarkan hasil penelitian diketahui bahwa: Hasil identifikasi menunjukkan bahwa, kondisi pesisir Teluk Kupang khususnya di Kelurahan LLBK, sangat rentan terhadap keruntuhan dan kerusakan bangunan serta infrastrukturnya, adanya pencemaran laut oleh limbah rumah tangga dan industri kecil di sekitar kawasan ini, dan lemahnya penegakan aturan dalam hal pembangunan di kawasan ini. Berdasarkan penyebabnya, kerusakan pesisir di kawasan ini secara umum disebabkan oleh aktifitas manusia berupa pembangunan gedung dan infrastruktur yang sangat dekat dengan garis pantai sehingga menjadi benteng bagi gempuran ombak dan faktor alam yaitu gelombang badai yang selalu terjadi secara periodik setiap tahunnya. Untuk mengurangi dampak/resiko kerugian yang mungkin dapat terjadi, maka diusulkan beberapa alternatif yang dapat dilakukan yaitu: pendekatan struktur berupa pembuatan tembok pantai dan revetment pada lokasi yang bukan karang, sedangkan pada lokasi karang dibuat revetment dan perlu dilakukan studi lebih lanjut guna menentukan tingkat kelayakan dan kemampuan dari karang-karang tersebut dalam menahan beban yang setiap hari terus meningkat, sehingga dapat ditentukan alternatif penanganan yang lebih baik. Sedangkan untuk pendekatan non struktur dilakukan melalui sosialisasi dan penegakan aturan pembangunan.
\end{abstract}

Kata kunci: Pesisir, kerusakan \& upaya perbaikan

\section{PENDAHULUAN}

Indonesia sebagai negara kepulauan terbesar di dunia yang memiliki 17.508 pulau dengan panjang garis pantai $81.000 \mathrm{~km}$, memiliki potensi sumberdaya pesisir dan lautan yang sangat besar (Bengen, 2001 dalam Desniarti, 2002). Kawasan pesisir memiliki nilai strategis sebagai multiple-use zone karena memiliki kemudahan akses transportasi, lahan darat dan perairan yang subur, relative murah dan mudah sebagai tempat pembuangan limbah, kemudahan akses mendapatkan water cooling untuk industri, dan keindahan panorama (Yuwono,2007).

Oleh karena itu hampir semua kota besar di Indonesia berada di wilayah pesisir. Kota Kupang sebagai ibukota Provinsi Nusa Tenggara Timur juga merupakan salah satu kota di Indonesia yang berada di wilayah pesisir.

Kondisi wilayah pesisir Kota Kupang saat ini sudah sangat padat oleh bangunan dan infrastruktur lainnya. Bahkan gedunggedung pertokoan, kawasan permukiman,dan kawasan pariwisata serta beberapa infrastruktur seperti jalan raya dan areal parkiran, hotel serta pasar dibangun tepat pada bibir pantai yang merupakan daerah bantaran pantai.

Salah satu masalah yang dihadapi oleh kota Kupang saat ini adalah rusaknya berbagai infrastruktur yang ada di sekitar wilayah pesisir khususnya kawasan wisata pantai, akibat terjangan gelombang badai yang sering terjadi setiap tahun terutama saat musim barat (musim hujan yang disertai badai yang terjadi antara bulan Desember - Februari). Salah satu 
lokasi wisata di pesisir Teluk Kupang yang paling sering mengalami kerusakan adalah kawasan wisata di kelurahan Lai-Lai Besi Kopan (LLBK). Lokasi-lokasi ini secara khusus oleh pemerintah telah dibangun berbagai infrastruktur pendukung untuk menunjang Pariwisata di Kota Kupang berupa jalan setapak menyusuri pantai, lopo-lopo tempat beristirahat, taman dan arena bermain. Namun Daerah-daerah ini selalu mengalami kerusakan setiap tahun akibat terjangan gelombang badai musim Barat tersebut. Akibatnya setiap tahun Pemerintah Kota Madya Kupang harus mengeluarkan dana guna perbaikan daerah-daerah tersebut.

Dengan memperhatikan kondisi permasalahan di atas maka, penulis tertarik untuk melakukan penelitian ini dengan memilih judul : "Studi Identifikasi dan Penanganan Terhadap Kerusakan Pantai di Kawasan Wisata Pesisir Teluk Kupang".

\section{METODE PENELITIAN}

\section{Tahapan Penelitian}

1. Pengumpulan Data

Data yang dikumpulkan berupa data Primer dan data Sekunder. Data Primer diperoleh melalui hasil survey dan kajian di lapangan berupa data situasi lapangan. Sedangkan data sekunder diperoleh dari instansi terkait, meliputi : Peta rupa bumi digital Indonesia, Data titik-titik pusat gempa di sekitar Samudra Hindia diperoleh dari web site BMKG, Data Kupang dalam Angka yang diperoleh dari Dinas Statistik Kota Kupang dan Foto udara Teluk Kupang yang diperoleh melalui website: google earth

2. Pengolahan Data dan Analisa

Data hasil identifikasi kerusakan yang telah dikumpulkan, selanjutnya diolah untuk menentukan penyebab dan tingkat kerusakan yang terjadi pada wilayah sekitar Pesisir Teluk Kupang. Hasil analisa ini selanjunya dikaji guna menentukan upaya untuk memitigasi kawasan Pesisir Teluk Kupang yang teridentifikasi selalu mengalami kerusakan guna meminimalisir kerusakan dan kerugian yang mungkin terjadi.

3. Kajian yang dilakukan berdasarkan konsep pengamanan dan perlindungan wilayah pantai sebagai upaya mitigasi bencana pesisir adalah melindungi dan mengamankan antara lain (Bambang Triatmodjo,2007):

a) masyarakat yang tinggal di sepanjang pantai dari ancaman gelombang

b) fasititas umum yang berada di sepanjang pantai

c) dataran pantai terhadap ancaman erosi dan abrasi

d) perlindungan alami pantai dari pengrusakan akibat kegiatan manusia

e) terhadap pencemaran lingkungan perairan pantai

Tingkat prioritas pengamanan pantai terkait dengan sumberdaya dan fasilitas di daerah pantai adalah:

\section{Prioritas tinggi :}

- Kawasan yang padat penduduk

- Banyak fasilitas umum (masjid, gereja, jalan raya, pasar)

- Kawasan yang mempunyai nilai ekonomis tinggi (wisata, industri, pertokoan)

Prioritas rendah :

- Kawasan kosong,

- sumber material,

- bukit pasir, dan

- hutan

Konsep pengamanan dan perlindungan pantai dapat dilihat pada gambar 2.1.

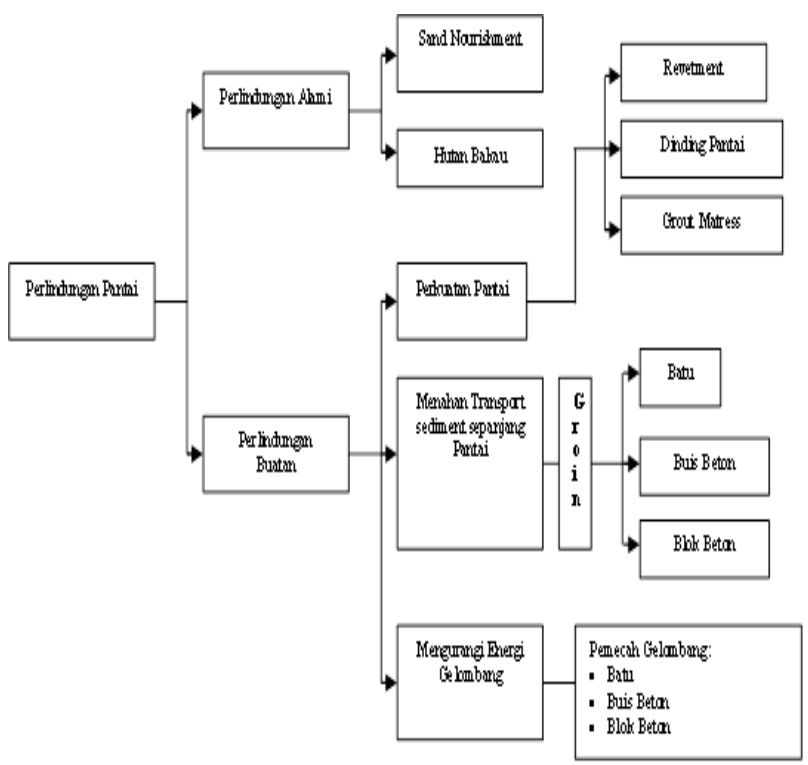
Gambar 1 Bagan Konsep Perlindungan
Pantai

(Sumber: Bambang Triatmodjo,2007)

Alternatif Mitigasi yang dapat dilakukan dapat dilihat pada tabel 2.1.

Tabel 2.1. Tabel alternatif Mitigasi 
Priska Gardeni Nahak ${ }^{1^{\star}}$, Melchior Bria², Mathelda C.H. Mauta ${ }^{3}$

\begin{tabular}{|c|c|c|}
\hline Pendekatan & Metode & Keterbatasan \\
\hline $\begin{array}{l}\text { Manajemen } \\
\text { Lahan }\end{array}$ & $\begin{array}{l}\text { - Penyesuaian } \\
\text { Pengembangan } \\
\text { - Hidup dengan } \\
\text { erosi } \\
\text { - Pengelolaan Zona } \\
\text { - Penyangga } \\
\text { (buffeer zone) }\end{array}$ & $\begin{array}{l}\text { - Kadang tak } \\
\text { dikehendaki } \\
\text { - Butuh } \\
\text { kesiagaan } \\
\text { - Membutuhka } \\
\text { n ruang yang } \\
\text { luas }\end{array}$ \\
\hline Vegetasi & $\begin{array}{l}\text { Penanaman tanaman } \\
\text { pesisir: } \\
\text { - } \text { Mangrove } \\
\text { - } \text { Cemara } \\
\text { - } \\
\quad \text { Pandan,rumput, } \\
\text { dls. }\end{array}$ & $\begin{array}{l}\text { - Perlu waktu } \\
\text { lama } \\
\text { - Membutuhka } \\
\text { n lahan luas }\end{array}$ \\
\hline $\begin{array}{l}\text { Pengisian / } \\
\text { peremajaan } \\
\text { pantai }\end{array}$ & $\begin{array}{l}\text { Menambahkan pasir } \\
\text { pada pantai alami } \\
\text { yang ada }\end{array}$ & $\begin{array}{l}\text { - Untuk pantai } \\
\text { berpasir } \\
\text { - Sumber pasir } \\
\text { - Perlu } \\
\text { pemeliharaan }\end{array}$ \\
\hline $\begin{array}{l}\text { Perkuatan } \\
\text { Pantai }\end{array}$ & $\begin{array}{l}\text { - Headland } \\
\text { - Revetment } \\
\text { - Marsh sills }\end{array}$ & $\begin{array}{l}\text { Dampak pada } \\
\text { lingkungan } \\
\text { sekitar }\end{array}$ \\
\hline $\begin{array}{l}\text { Modifikasi } \\
\text { Transport } \\
\text { sedimen }\end{array}$ & - Groin & $\begin{array}{l}\text { Dampak pada } \\
\text { lingkungan } \\
\text { sekitar }\end{array}$ \\
\hline
\end{tabular}

Sumber: Nizam, 2007

Tahapan dalam perencanaan alternatif perkuatan dan perlindungan pantai (Nizam, 2007) adalah:

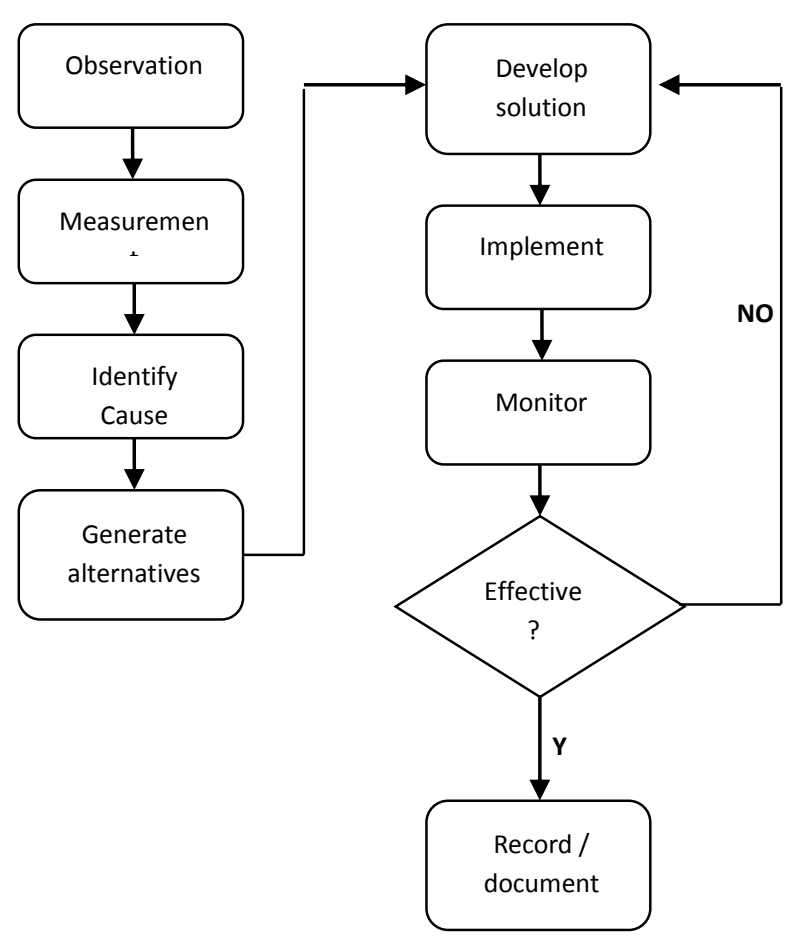

Gambar 2 Bagan Alir Tahap Perencanaan

\section{HASIL DAN PEMBAHASAN}

\section{A. Identifikasi Kondisi Pesisir Teluk Kupang}

Secara umum daerah pesisir Teluk Kupang telah berkembang, baik sebagai kawasan perdagangan, perikanan, pariwisata maupun permukiman. Hal ini menyebabkan Pesisir Teluk Kupang rentan terhadap berbagai perubahan yang bermuara pada kerusakan ekosistemnya.

Lokasi wisata di pesisir Teluk Kupang yang berkembang pesat saat ini adalah Pantai Tedys di kelurahan Lai-Lai Besi Kopan (LLBK). Lokasi ini merupakan pusat wisata kuliner yang sangat ramai oleh pengunjung setiap harinya, dan juga merupakan lokasi persinggahan kapal-kapal asing peserta Sail Indonesia dan Sail Komodo

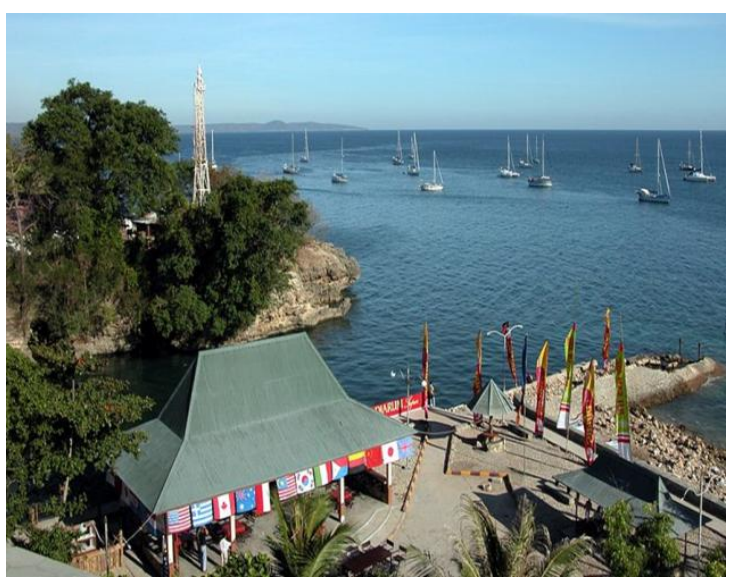

Gambar 3 Pantai Tedys saat Sail Indonesia Tahun 2004 sumber :

https://id.wikipedia.org/wiki/Kota_Kupang

Kawasan pesisir pantai di LLBK selain sebagai kawasan wisata, lokasi ini juga merupakan pusat perdagangan yang sangat ramai dan padat, sehingga sangat rentan terhadap berbagai kerusakan. Oleh sebab itu berdasarkan hasil pengamatan dan penelitian, maka dapat diidentifikasi beberapa kondisi Pesisir Teluk Kupang khususnya di Kelurahan LLBK, yaitu:

1. Lokasi wisata Pantai Tedys, oleh pemerintah kota dibangun taman kota dengan konstruksi dinding beton bertulang. berdasarkan hasil pengamatan, terlihat bahwa pada bagian dasar atau pondasinya mengalami erosi akibat terkikis oleh air laut. Hal ini terjadi karena 
tembok ini dibangun tepat di bibir pantai, sehingga terus digempur oleh gelombang.

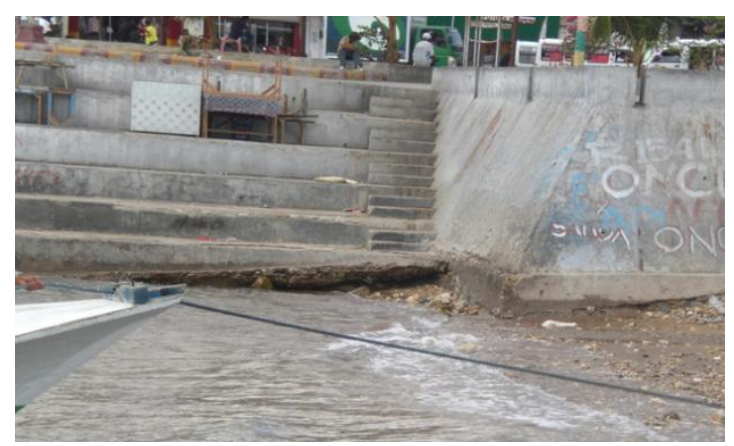

Gambar 4 Tembok Pantai di areal Wisata Pantai Tedys

2. Bangunan-bangunan pertokoan di sepanjang pesisir di Kelurahan ini, sudah dibangun sejak tahun 1950-an dan dibangun tepat di bibir pantai di atas karang terjal (gambar 4.3), sehingga bangunan-bangunan ini menjadi benteng bagi gempuran ombak, terutama pada saat badai musim barat yang selalu terjadi setiap tahun antara bulan Desember Februari. Hal ini menyebabkan bangunan di lokasi ini sangat rentan untuk dapat ambruk sewaktu-waktu. Runtuhnya bangunan di lokasi ini pernah terjadi pada tanggal 19 Agustus 2008 dini hari, di mana 3 (tiga) toko di lokasi ini roboh akibat umur patahnya karang penyanggah di bawah ke tiga bangunan tersebut (gambar 4.3 dan 4.4). Patahnya karang penyanggah ini terjadi karena bagian bawah karang tersebut telah mengalami erosi akibat terkikis oleh gelombang laut yang terus menerus, sehingga kemampuannya dalam memikul beban juga terus berkurang sedangkan beban yang dipikulnya terus bertambah seiring waktu. Akibatnya pada saat kemampuan karang tersebut dalam memikul beban terlampaui, maka karang tersebut akan patah sehingga bangunan di atasnya juga ikut runtuh. Runtuhnya bangunan di lokasi ini tidak menutup kemungkinan akan diikuti oleh runtuhnya bangunan-bangunan toko yang lain, karena umur bangunan di lokasi itu yang sudah semakin tua dan melemahnya karang penyanggah bangunan akibat tererosi oleh air laut

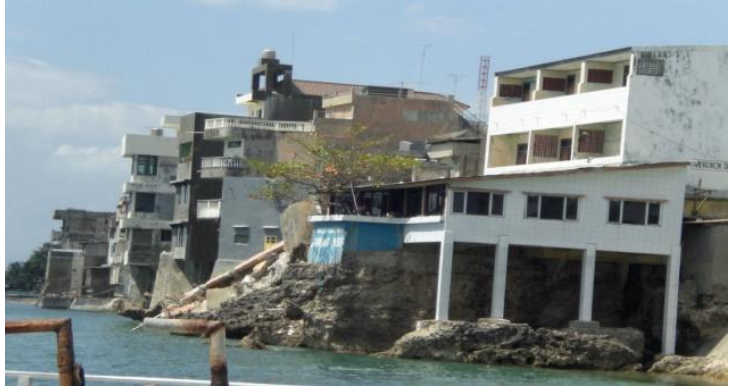

Gambar 5 Bangunan toko dibangun di bibir pantai di atas karang terjal

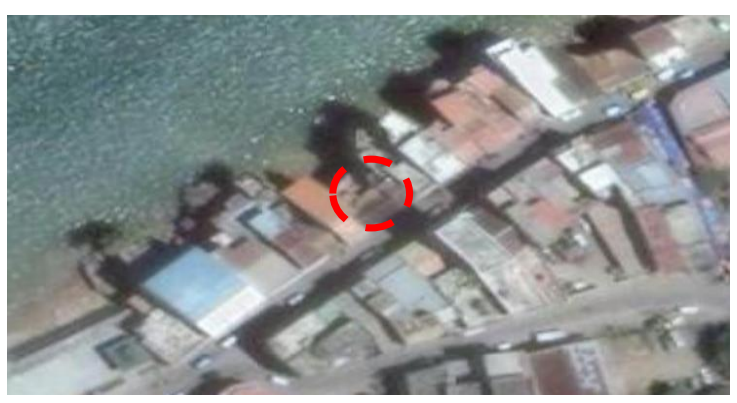

Gambar 6 Tiga bangunan toko yang ambruk pada tanggal 19 Agustus 2008 lalu, dilihat dari foto udara

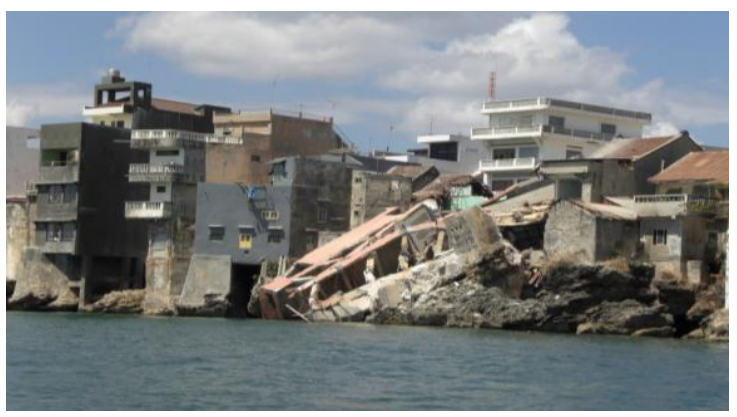

Gambar 7 Bangunan toko yang roboh ini dibangun tepat di bibir pantai, dilihat dari arah laut

3. Sebagai salah satu kawasan pusat perdagangan, kebutuhan akan lahan di kawasan ini menjadi sangat tinggi, sehingga beberapa lokasi yang dulunya merupakan daerah terbuka yang menjadi milik publik, kini telah berubah menjadi bangunan ruko. Pembangunan ruko ini menyebabkan tidak ada lagi lahan terbuka yang menjadi akses masyarakat untuk menikmati keindahan laut di lokasi ini. Hal ini menunjukkan lemahnya penegakan aturan pembangunan oleh Pemerintah Kota. 
Priska Gardeni Nahak ${ }^{1^{\star}}$, Melchior Bria ${ }^{2}$, Mathelda C.H. Mauta ${ }^{3}$

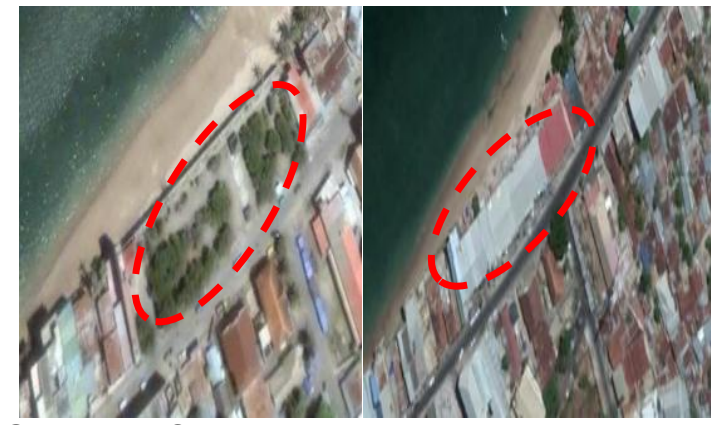

Gambar 8 Salah satu taman kota sebelum dan sesudah dibangun ruko

sumber: Google earth 2008 dan 2018

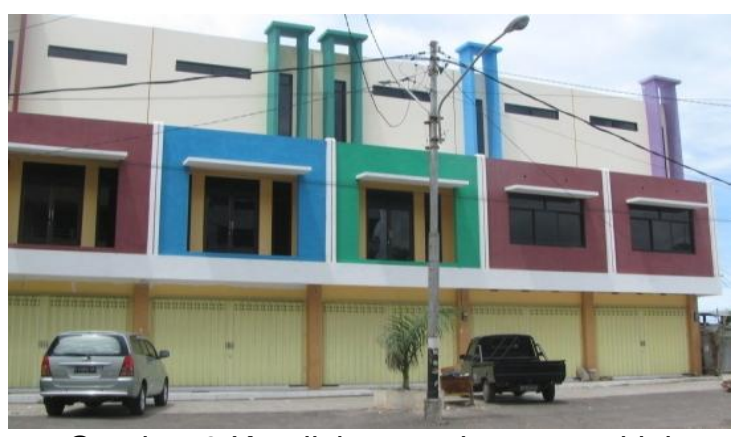

Gambar 9 Kondisi taman kota yang kini menjadi lokasi bangunan ruko

4. Kehadiran bangunan-bangunan pertokoan di sepanjang bibir pantai Teluk Kupang menjadi sumber pencemaran laut, di mana laut dijadikan sebagai septi tank umum dan tempat pembuangan limbah rumah tangga lainnya. Hal ini terlihat dari banyaknya saluran pembuangan yang langsung diarahkan ke laut (Gambar 4.7).

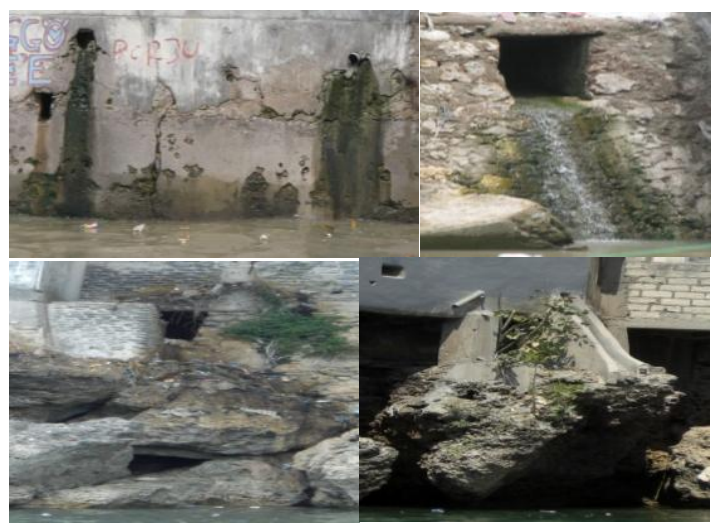

Gambar 10 Saluran pembuangan beberapa toko yang diarahkan langsung ke laut

5. Letak Pantai Tedys sebagai areal wisata kuliner, parkiran dan jalan raya yang sangat dekat dengan garis pantai, dengan ketinggiannya dari muka air laut $\pm 2 \mathrm{~m}$, mengakibatkan areal ini selalu mengalami kerusakan oleh terjangan gelombang badai yang terjadi setiap musim barat.
Pada saat terjadi gelombang badai, lokasi ini tidak dapat digunakan karena hempasan gelombang tersebut mencapai areal kuliner, parkir dan jalan raya, sehingga aktifitas di kawasan ini terpaksa dihentikan. Akibatnya terjadi kerugian yang cukup besar mengingat kawasan ini merupakan pusat wisata dan perdagangan yang strategis.

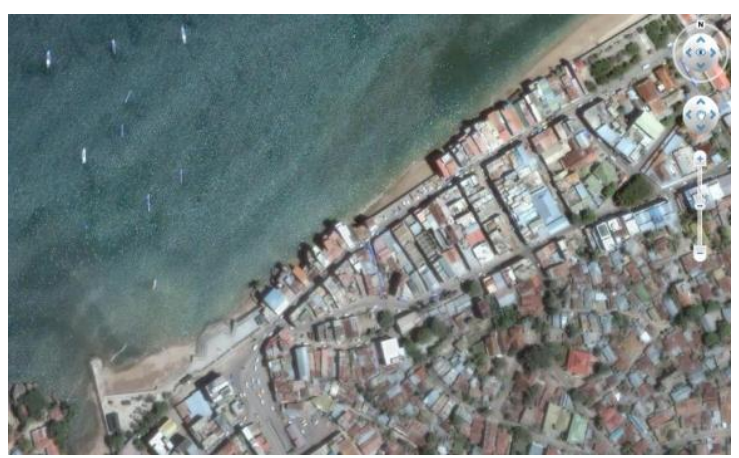

Gambar 11 Pantai Tedys areal parkiran serta jalan raya di Kelurahan LLBK

\section{B. Faktor-faktor Penyebab Kerusakan Pesisir Teluk Kupang}

Dilihat dari penyebabnya, kerusakan wilayah Pesisir Teluk Kupang umumnya disebabkan oleh:

1. Kerusakan pada Pesisir Teluk Kupang terutama disebabkan oleh aktifitas manusia yaitu pembangunan berbagai infrastruktur dan gedung di sepanjang daerah bantaran pantai, sehingga menjadi sasaran gempuran ombak pada saat musim barat tiba, akibatnya selalu mengalami kerusakan dan penurunan kekuatan. Selain itu, kondisi ini juga dapat menjadi sumber pencemaran terhadap lingkungan laut dan pesisir oleh limbah rumah tangga maupun industri kecil yang banyak tersebar di sepanjang pantai Teluk Kupang.

2. Kerusakan pada Pesisir Teluk Kupang, selain karena aktifitas manusia juga disebabkan oleh faktor alam terutama yaitu badai musim barat yang selalu terjadi setiap tahun antara bulan Desember hingga bulan Februari di Nusa Tenggara Timur. Gempuran ombak ini juga menyebabkan erosi pada dinding dan tebing karang yang merupakan penyanggah bangunan dan infrastruktur lainnya, sehingga tidak jarang terjadi keruntuhan bangunan dan infrastruktur di 
sekitar kawasan ini.

Kondisi pesisir Teluk Kupang membutuhkan perhatian serius guna menghindari kerusakan yang lebih parah, yang tentunya akan menjadi bencana bagi masyarakat pesisir Teluk Kupang itu sendiri. Untuk itu sangat perlu untuk dilakukan upayaupaya penanggulangan berupa mitigasi bencana guna meminimalkan kerugian yang ditimbulkan akibat bencana pesisir yang mungkin akan terjadi.

\section{Alternatif Mitigasi di Wilayah Pesisir Teluk Kupang}

Untuk mengurangi dampak/resiko kerugian yang mungkin dapat terjadi, maka diusulkan beberapa alternatif yang dapat dilakukan yaitu:

1. Pendekatan struktur

Kerusakan di kawasan pertokoan LLBK disebabkan oleh terjangan gelombang badai yang terjadi secara musiman (periodik) yaitu setiap musim barat. Kerusakan ini diperparah oleh letak areal ini yang sangat dekat dengan bibir pantai yaitu antara 0 sampai dengan $1 \mathrm{~m}$ dengan ketinggiannya dari muka air laut \pm $2 \mathrm{~m}$. Areal ini secara umum merupakan daerah pantai berkarang terjal yang diselingi dengan pantai berpasir, sehingga hampir semua infrastruktur dibangun di atas karang-karang terjal, tepat dibibir pantai. Akibatnya infrastruktur tersebut selalu menjadi sasaran gempuran ombak setiap hari dan terutama pada musim barat tiba, sehingga sering mengalami kerusakan dan keruntuhan.

Terjangan gelombang yang besar juga mencapai areal parkir dan jalan raya sehingga menggerus dan merusak aspal dan konstruksi areal parkiran, sehingga aktifitas yang melalui daerah ini terpaksa dihentikan. Akibatnya terjadi kerugian yang cukup besar mengingat kawasan ini merupakan pusat perdagangan strategis.

Untuk itu upaya perbaikan dan perlindungan pantai perlu dilakukan di kawasan ini. Adapun upaya yang ditawarkan adalah:

a) Pada Areal Pantai Tedys dan areal parkiran depan toko Arjuna, perlu dibuat tembok pantai yang dikombinasikan dengan revetment batu. Tembok pantai tidak dibangun sepanjang pantai, tetapi hanya pada bagian tertentu yang tidak terletak di atas batu karang

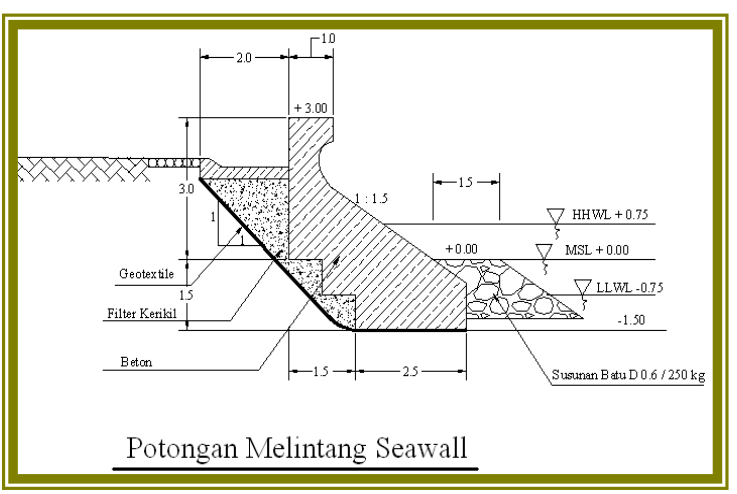

Gambar 12 Contoh kombinasi dinding laut dan revetment

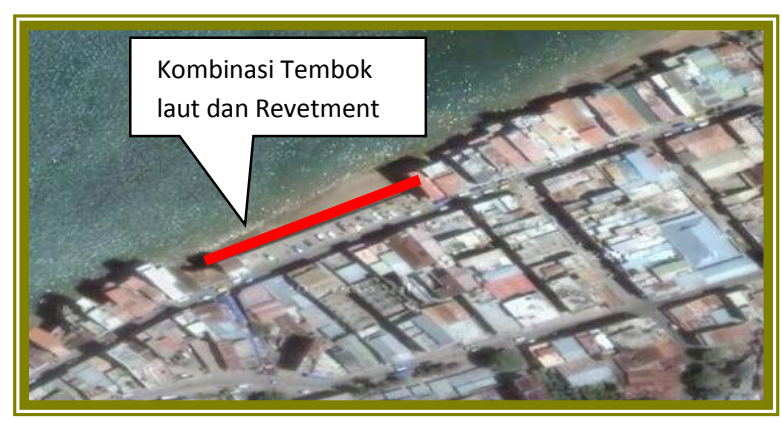

Gambar 13 Alternatif perlindungan tebing

b) Kawasan pantai karang terjal, alternatif untuk mengurangi erosi pada karang agar tidak lebih parah, maka untuk penanganan jangka pendek perlu segera dibuat revetmen batu atau buis beton guna mengurangi energi gelombang yang menghempas karang secara langsung. Sedangkan untuk penanganan jangka panjang perlu segera dilakukan studi guna menentukan tingkat kelayakan dan kemampuan dari karang-karang tersebut dalam menahan beban yang setiap hari terus meningkat, sehingga dapat ditentukan alternatif penanganan yang lebih baik.

c) Sedangkan untuk melindungi pantai dari terjangan gelombang terutama gelombang badai musim barat, maka disarankan untuk membuat breakwater di sepanjang kawasan pertokoan (Kawasan pertokoan LLBK dan Kampung Solor) baik dengan konstruksi menerus maupun dengan konstruksi berlubang. Dengan adanya breakwater ini diharapkan dapat mengurangi energi gelombang sehingga dapat mengurangi dampak kerusakan yang mungkin terjadi. 
Priska Gardeni Nahak ${ }^{1^{\star}}$, Melchior Bria ${ }^{2}$, Mathelda C.H. Mauta ${ }^{3}$

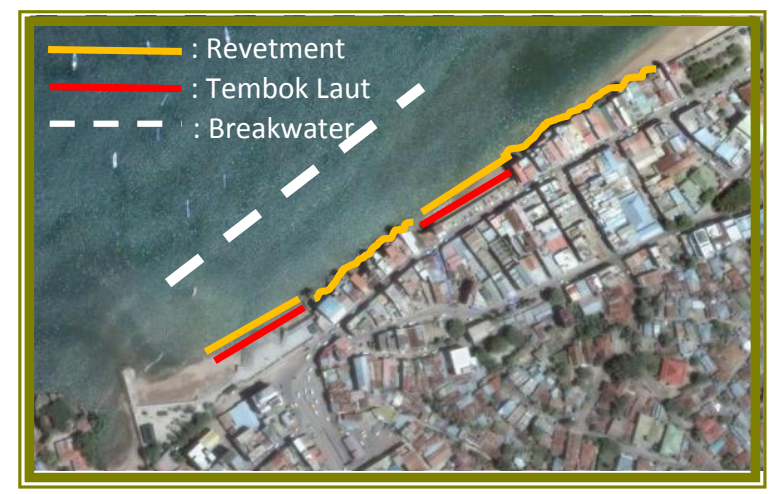

Gambar 14 Alternatif perlindungan pantai

2. Pendekatan non struktur

Perlu dilakukan pendekatan non struktural, berupa sosialisasi tentang bahaya dan dampak kerugian yang dapat terjadi, bagi masyarakat baik penghuni maupun pengunjung kawasan ini sehingga mereka lebih waspada terhadap bahaya yang dapat terjadi sewaktu-waktu. Bila memungkinkan sebaiknya dilakukan relokasi guna menghindari dampak dan kerugian yang lebih parah, namun mungkin akan sulit untuk dilaksanakan karena kawasan ini sudah terlanjur tumbuh dan berkembang menjadi salah satu pusat perdagangan yang strategis. Namun jika ingin dipaksakan maka dapat dilakukan melalui penegakan aturan pembangunan dan relokasi kawasan, namun keberhasilan dan kemajuannya perlu dipertimbangkan.

\section{PENUTUP}

\section{Kesimpulan}

Berdasarkan hasil analisa, dan pembahasan di atas, maka dapat disimpulkan sebagai berikut:

1. Pesisir Teluk Kupang khususnya di kawasan Pantai Tedys dan pertokoan di Kelurahan LLBK, secara umum merupakan pantai berkarang terjal yang diselingi oleh pantai berpasir, menyebabkan hampir semua bangunan pertokoan maupun infrastruktur dibangun di atas karang terjal, tepat di bibir pantai. Akibatnya bangunan dan infrastruktur tersebut rentan terhadap kerusakan dan keruntuhan akibat gempuran ombak yang selalu terjadi terutama saat musim barat (antara bulan Desember - Februari)
2. Berdasarkan hasil identifikasi diketahui bahwa, kondisi pesisir Teluk Kupang khususnya kawasan wisata pantai Tedys dan pusat perdagangan di Kelurahan LLBK, sangat rentan terhadap keruntuhan dan kerusakan bangunan serta infrastrukturnya, adanya pencemaran laut oleh limbah rumah tangga dan industri kecil di sekitar kawasan ini, dan lemahnya penegakan aturan dalam hal pembangunan di kawasan ini.

3. Berdasarkan penyebabnya, kerusakan pesisir di kawasan ini secara umum disebabkan oleh aktifitas manusia berupa pembangunan gedung dan infrastruktur yang sangat dekat dengan garis pantai sehingga menjadi benteng bagi gempuran ombak dan faktor alam yaitu gelombang badai yang selalu terjadi secara periodik setiap tahunnya.

4. Untuk mengurangi dampak/resiko kerugian yang mungkin dapat terjadi, maka diusulkan beberapa alternatif yang dapat dilakukan yaitu: pendekatan struktur berupa pembuatan tembok pantai dan revetment pada lokasi yang bukan karang, sedangkan pada lokasi karang dibuat revetment dan perlu dilakukan studi guna menentukan tingkat kelayakan dan kemampuan dari karang-karang tersebut dalam menahan beban yang setiap hari terus meningkat, sehingga dapat ditentukan alternatif penanganan yang lebih baik. Sedangkan untuk pendekatan non struktur dilakukan melalui sosialisasi dan penegakan aturan pembangunan.

\section{Saran}

Perlu dilakukan sosialisasi tentang bahaya dan dampak kerugian yang dapat terjadi, bagi masyarakat baik penghuni maupun pengunjung kawasan ini sehingga mereka lebih waspada terhadap bahaya yang dapat terjadi sewaktu-waktu.

Perlu adanya komitmen pemerintah dalam menegakkan aturan terhadap pembangunan baru dan bila perlu sebaiknya dilakukan relokasi guna mengurangi beban di kawasan tersebut

\section{UCAPAN TERIMAKASIH}

Terima kasih kepada Politeknik Negeri Kupang yang telah mendanai penelitian ini melalui dana DIPA PNK Tahun Anggaran 2018, dengan Kontrak Nomor: 
29/PL23.PPK.PNBP/KU/2018

Tanggal: 06 Juli 2018

\section{DAFTAR PUSTAKA}

Bambang Triatmodjo, 2007, Pengelolaan Bencana Wilayah Pesisir, Bahan Kuliah Program Magister Pengelolaan Bencana Alam UGM, Yogyakarta

Desniarti, 2002, Faktor Pendorong Perubahan Lingkungan Wilyah Pesisir, Makalah, Program Pasca sarjana ITB, Bogor

Mastra Ris R., 2007, Penggunaan Citra untuk memantau perubahan dan kerusakan kawasan pantai, makalah, Departemen Kelautan dan Perikanan, Jakarta.

Nizam, 2007, Pengelolaan Bencana Wilayah Pesisir, Bahan Kuliah Program Magister Pengelolaan Bencana Alam UGM, Yogyakarta

Yuwono, 2007, Pengelolaan Bencana Wilayah Pesisir, Bahan Kuliah Program Magister Pengelolaan Bencana Alam UGM, Yogyakarta 